\title{
COVID-19 infections in pets such as cats and dogs
}

\author{
Mehmet Demirci ${ }^{1}$, Akın Yiğin², Bekir Sami Kocazeybek ${ }^{3}$, Oktay Keskin ${ }^{4}$ \\ ${ }^{1}$ Department of Medical Microbiology, Faculty of Medicine, Kırklareli University, Kırklareli, Turkey \\ ${ }^{2}$ Department of Genetic, Faculty of Veterinary Medicine, Harran University, Sanliurfa, Turkey \\ ${ }_{3}^{3}$ Department of Medical Microbiology, Faculty of Medicine, İstanbul University-Cerrahpaşa, İstanbul, Turkey \\ ${ }^{4}$ Department of Microbiology, Faculty of Veterinary Medicine, Harran University, Şanliurfa, Turkey
}

\section{Key Words: \\ SARS-CoV-2 \\ COVID-19 \\ cat \\ $\operatorname{dog}$}

coronaviruses

Anahtar Kelimeler:

SARS-CoV-2

COVID-19

kedi

köpek

koronavirus

$\begin{array}{ll}\text { Received } & : 17.06 .2021 \\ \text { Accepted } & : 06.12 .2021 \\ \text { Published Online } & : 31.12 .2021 \\ \text { Article Code } & : 953646\end{array}$

Correspondence:

O. KESKIN

(email: okeskin@harran.edu.tr)

\section{ORCID}

M. DEMIRCI $\quad$ : 0000-0001-9670-2426

A. YÏĞiN :0000-0001-9758-1697

BS. KOCAZEYBEK: 0000-0003-1072-3846

O. KESKIN :0000-0002-5977-7872

\begin{abstract}
Coronaviruses are a very large group of virus families that can cause diseases in both different animal species and humans. Infections with different coronaviruses are seen in cats and dogs. The epidemic of COVID-19 infection caused by the SARS-CoV-2 virus still continues all over the world. In this article, we aimed to compile published studies on COVID-19 infections in cats and dogs, which we are in close contact with. When the studies were examined, it was understood that cats were more sensitive to SARS-CoV-2 than dogs after contact with COVID-19 positive individuals in quarantine. Cats may show symptoms in case of infection, compared to dogs. The RBD region where SARS$\mathrm{CoV}-2$ binds to ACE2 receptors is reported more similar to humans in cats than dogs. ACE2 protein seemed very similar to humans in both cats and dogs compared to other mammals. ACE2 receptor is highly expressed in different tissues of them, according to the study data examined. In a conclusion, SARS-CoV-2 can be detected because ACE2 is frequently expressed in different tissues in domestic animals such as cats and dogs, and the binding site is similar to human ACE2 receptors. In order to prevent zoonotic infections such as COVID-19 infections during the epidemic period when different disciplines need to work together with a single health approach, we believe that molecular surveillance studies should be carried out on our close friends such as cats and dogs. The data should be presented in public database and followed.
\end{abstract}

\section{Kedi ve Köpeklerde COVID-19 Enfeksiyonları}

\section{ÖZ}

Koronaviruslar, hem farklı hayvan türlerinde, hem de insanlarda hastalıklara neden olabilen çok geniș bir virus ailesi grubudur. Kedi ve köpeklerde farklı koronaviruslarla enfeksiyonlar görülmektedir. SARS-CoV-2 virüsü tarafindan oluşturulan COVID-19 enfeksiyonu salginı tüm dünyada halen devam etmektedir. Bu derlemede insanlarla yakın temasta bulunan kedi ve köpeklerde COVID-19 enfeksiyonları ile ilgili yayınlanan çalışmaların değerlendirilmesi amaçlandı. Yapılan çalışmalar incelendiğinde, karantinadaki COVID-19 pozitif bireylerle temasları sonrası kedilerin, SARS-CoV2’ye köpeklere göre daha duyarlı olduğu anlaşılmaktadır. Kediler enfeksiyon durumunda köpeklere göre semptom gösterebilmektedir. SARS-CoV-2'nin ACE2 reseptörlerine bağlandığ1 RBD bölgesinin, kedilerde köpeklere kıyasla insanlara daha fazla benzerlik gösterdiği bildirilmiştir. Diğer memelilere göre hem kedi, hem de köpeklerde ACE2 proteini insanlara oldukça benzer olduğu görülmüştür. İncelenen çalışma verilerine göre, kedi ve köpeklerin farklı dokularında ACE2 reseptörü yüksek oranda eksprese edilmektedir. Sonuç olarak, SARS-CoV-2 kedi ve köpek gibi evcil hayvanlarda ACE2'nin farklı dokularında sıklıkla eksprese edilmesi ayrıca bağlanma bölgesinin insan ACE2 reseptörlerine benzer olmaları dolayısıyla tespit edilebilmektedir. Tek sağlık yaklaşımı ile farklı disiplinlerin birlikte çalışması gereken salgın döneminde COVID-19 enfeksiyonları gibi zoonotik enfeksiyonların önlenebilmesi için kedi ve köpek gibi yakın dostlarımızda moleküler surveyans çalışmalarının yapılması ve verilerin açık veritabanlarında sunularak takiplerinin yapılması gerektiği kanaatindeyiz.

\section{INTRODUCTION}

Coronaviruses are a very large group of virus families that can cause diseases in both different animal species and humans. Animal coronaviruses can also cause different diseases in the respiratory tract, gastrointestinal system and / or neurological systems of a wide variety of hosts, as in humans (1). "Coronavirus disease 2019 (COVID-19)" and its causative agent "severe acute respiratory syndrome coronavirus-2" (SARS-CoV-2), is a virus in the Coronaviridae family which was first encountered in cases of infection of unknown cause at Wuhan province of China, in December 2019 (2).

The first coranavirus species that is important in terms of global health was the severe acute respiratory syndrome coronavirus (SARS-CoV) in 2003, and it was reported that the source of transmission to humans was Horseshoe bat (Rhinolophus ferrumequinum) species. Less than a decade later, the Middle East respiratory syndrome (MERS) disease, also caused by a coronavirus (MERS-CoV), emerged and 
became an endemic disease in the Middle East, Africa and Southeast Asia. Although the zoonotic origins of MERS-CoV remain unclear, it was estimated that the virus was transmitted from bat species to dromedary camels in the past and these camels could also be the source (3).

In SARS-CoV-2, although the first source of the virus that causes disease is not known clearly, it has been reported that the first cases diagnosed are linked to the Huanan Seafood Wholesale Market, where people can buy wild animals such as bats (2). In this market, before the epidemic, a wide variety of live animals were sold, including fish and shellfish, as well as hedgehogs, badgers, snakes and poultry. In addition, there were animal food products as well as livestock sales (3).

SARS-CoV-2 has so far been effective in 216 countries all over the world, infected nearly 121 million people and caused the death of nearly 2.7 million people (4). Despite the high number of cases encountered in humans, the number of data supporting reverse zoonotic transmission of SARS$\mathrm{CoV}-2$ is limited. However, there were reports that animals become infected after close contact with infected people or their quarantine owners with domestic animals and animals in zoos $(3,5)$. Although the number of cases in humans is followed, this situation in animals is not followed, considering that pet owners may leave these animals in panic. In fact, there are publications reporting that cat and dog species have seroconversion and SARS-CoV-2 infection after these reverse transmissions $(5,6)$.

Coronavirus infections in animals are usually enzootic and can affect certain species for a long time. The exceptional replication mechanisms of coronaviruses and the possibility of recombination events that may occur during their reproduction are two main factors that can lead to interspecies and interspecies transitions of coronaviruses and elevated their zoonotic potential. Therefore, understanding coronavirus infections in animals that frequently live as friends and are in close contact with humans, such as cat and dog species, is crucial to understanding different aspects of the ecology and evolution of coronaviruses $(1,5,7,8)$.

In order to prevent viral zoonotic infections such as COVID-19 infections during the epidemic period when different disciplines need to work together with an one health perspective, it is important to understand not only human health but also how the animals affected for this situation (6). Aim of this study was to review published studies on COVID-19 infections in cats and dogs, which we are in close contact with.

\section{SARS-CoV-2 Morphology and zoonotic potential}

In electron microscopy negative staining, it is seen that SARS-CoV-2 contains lipid bilayer, viral RNA and structural proteins derived from the host membrane with a diameter of 90/120 nm. Being members of the betacoronavirus genus in Coronaviridae family, SARS-CoV-2 contains four structural proteins called S (spike), E (envelope), M (membrane) and $\mathrm{N}$ (nucleocapsid) proteins. The $\mathrm{S}$ protein has a very critical role for entry into the host cell (7). SARS-CoV-2 infects human cells by binding to the cell surface protein angiotensin converting enzyme 2 (ACE2) via the Receptor Binding Domain (RBD) of the $S$ protein, at this stage the cellular transmembrane serine protease 2 (TMPRSS2) is required to cut the viral S protein and make it ready (9). This receptor is found in all major vertebrate groups. The results of the study to estimate host sensitivity based on amino acid sequence similarity between human ACE2 (hACE2) receptors and non-human ACE2 receptors; demonstrated that hACE2 has a high degree of similarity with the viral binding site, which are amino acid residues in which it interacts with the SARS-CoV-2 spike glycoprotein (10).

\section{COVID-19 infections detected in cat and dog species}

Feline coronaviruses (FCoVs), members of the alphacoronavirus genus in Coronaviridae family, are widely known coronavirus members as agents that can infect both domestic and wild cats. There are 2 subtypes as FCoV I and II subtypes. While FCoV type $\mathrm{I}$ is known as the main subtype, FCoV type II is formed as a result of the alteration of feline coranaviruses (FCoV type I) by recombination with canine coronaviruses $(\mathrm{CCOV})$, which is also a member of the alphacoranavirus genus, which is frequently detected in dogs (11).

Canine coronavirus $(\mathrm{CCoV})$, which is common coronavirus in dogs and has two subtypes, type I and type II, just like FCoV. In dogs, canine respiratory coronavirus (CRCoV), which is a member of the betacoronavirus genus, also causes infections (11).

While it has been determined in studies that the COVID-19 agent, SARS-CoV-2, replicates in the nose and throat of cats and can cause deeper inflammatory pathology in the respiratory tract and the virus can cause airborne transmission among cats, it has been observed that dogs are less sensitive and do not support viral replication well $(12,13)$.

Viruses similar to SARS are betacoronaviruses of the B lineage and are quite different from each other with feline coronaviruses (alphacoronaviruses). Therefore, there is currently no conclusive evidence that prior exposure to $\mathrm{FCoV}$ will protect against SARS-like viruses; however, serological tests will need to carefully evaluate any potential cross-reactions. As a betacoronavirus member of lineage $\mathrm{A}, \mathrm{CRCoV}$ is relatively far away from SARS-like betacoronaviruses, including SARS$\mathrm{CoV}$ from lineage B. Previous exposure to $\mathrm{CRCoV}$ or $\mathrm{CCOV}$ is also unlikely to protect against SARS-like conditions (11).

The first cat in Hong Kong to test positive for SARS-CoV-2 was a domestic short-haired cat quarantined with its COVID-19 positive owner. It was found to be positive for SARS-CoV-2 RNA in swabs of the mouth, nose and rectum. The cat did not show any signs of illness. Experimental studies have shown that cats can have large amounts of the virus in their nasal mucosa and other tissues and release enough virus to allow for cat-to-cat transmission (14). The first case reported in Europe was a cat living in Belgium with its self-isolating owner after developing clinical symptoms one week after his return from Italy and testing positive for SARS-CoV-2 (15). SARS-CoV-2 was detected in two different cats detected by CDC and USDA 
in the United States in relation to their COVID-19 positive owners (16). Apart from these, cases of COVID-19 infection associated with human transmission in such cats have been reported in many countries such as France, Spain, Germany, the United Kingdom and Switzerland (17).

Similarly, in dogs, SARS-CoV-2 was detected in 2 out of 15 dogs (in a Pomeranian and a German shepherd species) in a quarantine with its owner in Hong Kong (18). Angiotensin converting enzyme 2 (ACE2) is known to be the human receptor for SARS-CoV-2, but ACE2 receptors in dogs were also found similar to humans. It has been reported that five of the 18 amino acids known to be involved in the interaction between the human ACE2 receptors, the receptor binding domain (RBD) of SARS-CoV-2, differ only between humans and dogs. It has been reported that none of the amino acid residues that cause this difference are regions known to impair the interaction between the RBD of SARS-CoV-2 and ACE2 receptors (18). SARS-CoV-2 positivity in dogs has also been reported in other studies, but when the data were examined, it was found that clinical findings were not frequently seen in dogs (19). Since the beginning of the epidemic, data have shown that it is possible for SARS-CoV-2 to be transmitted from humans to dogs (18). Also, according to the available data, dogs are now considered to be less susceptible hosts to SARS-CoV-2 than cats. Cats may be more sensitive because only 4 amino acid residues differ between cats and humans in the region of the SARS-CoV-2 RBD, which is required to bind to the ACE2 receptor (19). In another study supporting these data, phylogenetic similarity studies based on ACE2 protein sequences using genomic data showed that cats and dogs were the closest clustered species among all mammals included in this analysis. It has been demonstrated that the ACE2 gene is highly expressed in various tissues in these animals, interestingly, it appears that cats express more in lung tissues than dogs. This may be one of the evidence that may explain why dogs are less sensitive than cats (20).

Donnik et al (2021) stated in their study that cats were used as an experimental model for some coronovirus or other viral infections and that they were used as a model for COVID-19 infections due to their similarity with SARS-CoV. They reported that members of the Felidea family could only get SARS$\mathrm{CoV}-2$ infections under conditions where very close contact and titer of the virus could reach titers close to experimental models. In this review, where they stated that these conditions could not be met, they emphasized that although the infection was shown in experimental models against SARS-CoV in an 18-year period, not a single case of transmission or reverse transmission was observed. They even commented that the SARS-CoV-2 infections to be detected in these animals would be a biological dilemma for these viruses (21). In the same review, in the evaluation made for dogs, they reported that dogs were not sensitive to SARS-CoV-2 for the following two reasons.1. Failure to detect the virus in dogs, although dogs were vaccinated intranasally with very high virus titers in the experimental setting.and 2. No antibodies against SARSCoV-2 have been detected in dogs in China during the time of outbreak.They stated that these situations indicated that dogs were not involved in the transmission of this virus (21).
In their study, Chiba et al. (2021), stated that SARS-CoV-2 infections are an unsuitable animal model for cats to see the long-term effects of acute respiratory infections in cats. In this study, they investigated the histopathological changes in the lung tissues of cats that were euthanized on the 28th day and reported that they encountered differentiated lung lesions similar to chronic infection characteristics. however it was also concluded that domestic cats can be protected from reinfections after primary infection (22).

In their silico analysis study, Rendon-Marin et al examined the homology models of the SARS-CoV-2 spike protein RBD region, which binds with ACE2 receptors, by molecular docking methods in different animal species. They reported that feline cellular ACE2 receptors can interact with the RBD region of the SARS-CoV-2 spike protein and that it shared the same virus binding interface as hACE2. On the other hand, they found that dogs were unable to interact stably with the RBD region of the SARS-CoV-2 S protein cellular ACE2 receptors (23).

When Micheal et al. (2021), examined the respiratory tract samples obtained from cats and dogs at different regions of the World in early 2020 in terms of respiratory pathogens including SARS-CoV-2 with real-time PCR method, they reported that did not detect SARS-CoV-2 RNA in any of the 4616 samples (24). Villanueva-Saz et al. (2021), reported that they detected SARS-CoV-2 seropositivity in 4 out of 114 stray cats in their study (25). Klaus et al, (2021), with a case report, explained that they detected long-term seropositivity in a cat in Italy. This cat showed respiratory symptoms and the SARSCoV-2 RNA result was also positive (26).

As $\mathrm{Na}$ et al (2021), reported in their studies, coronaviruses members had considered as an underestimated pathogen until the SARS-CoV epidemic in 2003 Considering that it was described in 1931, despite 90-years period, our knowledge about coronaviruses is still limited (27). Bonilauri and Rugna recommended that maintaining veterinary controls of zoonotic diseases for early detection of SARS-CoV-2 in animals. They stated that the positivity of SARS-CoV-2 in animals should be examined systematically and the importance of determining the molecular epidemiology of the strain in these animals by sequencing methods. They stated that these data should be submitted public database in order to avoid dangerous variants (28). Although increasing numbers of SARS-CoV-2 infections have been reported in dogs and cats, long-term follow-up studies evaluating the persistence of antibodies developed in these animals and seroconversion status were still limited (29, 30). Decaro et al. (2021), Dileepan et al., (2021), and Y1lmaz et al, (2021) showed that cats and dogs develop specific and neutralizing antibodies against SARS-CoV-2 as in humans, but new studies are needed to understand how the presence of these specific and neutralizing antibodies protects these animals $(29,30,31)$. Recently, Y1lmaz et al. (2021), revealed that the situation in cats from our country is not different from other countries (31). Due to the nature of the virus, it is not surprising that it is similarly seen in our country $(2,32$, 33) In recent studies, SARS-CoV-2 virus and its variants have also been detected in cats, dogs and their owners, genomic 
characterizations have been made and it has been revealed that SARS-CoV-2 positive individuals should have limited contact with these animals (34).

\section{CONCLUSION}

As a conclusion, COVID-19 infection and its agent, SARS$\mathrm{CoV}-2$, can be detected because ACE2 is frequently expressed in different tissues in domestic animals such as cats and dogs, and the binding site is similar to human ACE2 receptors. However, binding to these receptors does not appear to be strong, especially in dogs. It should always be kept in mind that coronaviruses are a large family, there may be different coronavirus members in cats and dogs, and the similarity of these viruses in their replication mechanisms. In order to prevent viral zoonotic infections such as COVID-19 infections during the pandemic period in which different disciplines need to work together with a one health perspective, we believe that molecular surveillance studies should be carried out in our close friends such as cats and dogs, and the data should be presented in public database and followed up.

\section{DECLARATIONS}

\section{Ethics Approval}

This document does not require an ethics committe approval.

\section{Conflict of Interest}

Authors declare that there is no conflicts of interest for this study.

\section{Author Contribution}

All authors contributed to every step of the article.

\section{Data Availability}

The data that support the findings of this study are available from the corresponding author upon reasonable request

\section{REFERENCES}

1. Colina SE, Serena MS, Echeverría MG, Metz GE. Clinical and molecular aspects of veterinary coronaviruses. Virus Res. 2021;297:198382. doi:10.1016/j.virusres.2021.198382

2. Demirci M, Ünlü Ö, Yiğin A, Yıldız Zeyrek F. SARSCoV-2 patogenezi ve Covid-19'da immün yanıt. Turk Mikrobiyol Cemiy Derg. 2020;50(4):183-91

3. Hedman HD, Krawczyk E, Helmy YA, Zhang L, Varga C. Host Diversity and Potential Transmission Pathways of SARSCoV-2 at the Human-Animal Interface. Pathogens. 2021; 10(2):180. https://doi.org/10.3390/pathogens10020180

4. World Health Organization (WHO), Coronavirus disease (COVID-19) Pandemic. [https://www.who.int/emergencies/ diseases/novel-coronavirus-2019] (Erişim tarihi: 18.03.2021.)

5. Saegerman C, Bianchini J, Renault V, Haddad N, Humblet MF. First expert elicitation of knowledge on drivers of emergence of the COVID-19 in pets. Transbound Emerg Dis. 2020;10.1111/tbed.13724. doi:10.1111/tbed.13724
6. Yoo HS, Yoo D. COVID-19 and veterinarians for one health, zoonotic- and reverse-zoonotic transmissions. J Vet Sci. 2020;21(3):e51. doi:10.4142/jvs.2020.21.e51

7. Siddiqa MA, Rao DS, Suvarna G, Chennamachetty VK, Verma MK, Rao MVR. In-Silico Drug Designing of Spike Receptor with Its ACE2 Receptor and Nsp10/Nsp16 MTase Complex Against SARS-CoV-2. Int J Pept Res Ther. 2021;1-8. doi:10.1007/s10989-021-10196-x

8. Atlı K, Saltık HS, Yıldırım Y. Impact of weather conditions and global warming on COVID-19 outbreak. Eurasian Journal of Veterinary Sciences. 2020; 0(Covid-19 Special Issue): 118 121. Doi: 10.15312/EurasianJVetSci.2020.287

9. Trougakos, I.P., Stamatelopoulos, K., Terpos, E. et al. Insights to SARS-CoV-2 life cycle, pathophysiology, and rationalized treatments that target COVID-19 clinical complications. J Biomed Sci 2021;28:9. dpi:10.1186/s12929020-00703-5

10. Fischhoff IR, Castellanos AA, Rodrigues JPGLM, Varsani A, Han BA. Predicting the zoonotic capacity of mammal species for SARS-CoV-2. Preprint. bioRxiv. 2021.02.18.431844. doi:10.1101/2021.02.18.431844

11. Stout AE, André NM, Jaimes JA, Millet JK, Whittaker GR. Coronaviruses in cats and other companion animals: Where does SARS-CoV-2/COVID-19 fit? Vet Microbiol. 2020;247:108777. doi: 10.1016/j.vetmic.2020.108777.

12. Shi J, Wen Z, Zhong G, Yang H, Wang C, Huang B, Liu R, He X, Shuai L, Sun Z, Zhao Y, Liu P, Liang L, Cui P, Wang J, Zhang X, Guan Y, Tan W, Wu G, Chen H, Bu Z. Susceptibility of ferrets, cats, dogs, and other domesticated animals to SARS-coronavirus 2. Science. 2020;368(6494):1016-1020. doi: 10.1126/science.abb7015.

13. Saltık HS, Atlı K, Kale M. Severe acute respiratory syndrome coronavirus 2 (SARS-CoV-2): pathogenesis and virus-host interactions. Eurasian Journal of Veterinary Sciences. 2020; 0(Covid-19 Special Issue): 59 - 64. doi: 10.15312/EurasianJVetSci.2020.288.

14. Barrs VR, Peiris M, Tam KWS, Law PYT, Brackman CJ, To EMW, Yu VYT, Chu DKW, Perera RAPM, Sit THC. SARS-CoV-2 in Quarantined Domestic Cats from COVID-19 Households or Close Contacts, Hong Kong, China. Emerg Infect Dis. 2020;26(12):3071-3074. doi: 10.3201/ eid2612.202786.

15. Garigliany M, Van Laere AS, Clercx C, Giet D, Escriou N, Huon C, van der Werf S, Eloit M, Desmecht D. SARSCoV-2 Natural Transmission from Human to Cat, Belgium, March 2020. Emerg Infect Dis. 2020;26(12):3069-3071. doi: 10.3201/eid2612.202223.

16. Newman A, Smith D, Ghai RR, et al. First Reported Cases of SARS-CoV-2 Infection in Companion Animals New York, March-April 2020. MMWR Morb Mortal Wkly Rep 2020;69:710-713. doi: 10.15585/mmwr.mm6923e3 
17. Hosie MJ, Hofmann-Lehmann R, Hartmann K, et al. Anthropogenic Infection of Cats during the 2020 COVID-19 Pandemic. Viruses. 2021;13(2):185. doi:10.3390/v13020185.

18. Sit, T.H.C., Brackman, C.J., Ip, S.M. et al. Infection of dogs with SARS-CoV-2. Nature 2020;586:776-778 doi:10.1038/s41586-020-2334-5

19. do Vale B, Lopes AP, Fontes MDC, Silvestre M, Cardoso L, Coelho AC. Bats, pangolins, minks and other animals - villains or victims of SARS-CoV-2?. Vet Res Commun. 2021;45(1):1-19. doi:10.1007/s11259-021-09787-2

20. Sun K, Gu L, Ma L, Duan Y. Atlas of ACE2 gene expression reveals novel insights into transmission of SARSCoV-2. Heliyon. 2021;7(1):e05850. doi: 10.1016/j.heliyon.2020. e05850.

21. Donnik IM, Popov IV, Sereda SV, Popov IV, Chikindas ML, Ermakov AM. Coronavirus Infections of Animals: Future Risks to Humans. Biol Bull Russ Acad Sci. 2021;48(1):26-37. doi:10.1134/S1062359021010052

22. Chiba S, Halfmann PJ, Hatta M, et al. Protective Immunity and Persistent Lung Sequelae in Domestic Cats after SARS-CoV-2 Infection. Emerg Infect Dis. 2021;27(2):660663. doi:10.3201/eid2702.203884

23. Rendon-Marin S, Martinez-Gutierrez M, Whittaker GR, Jaimes JA, Ruiz-Saenz J. SARS CoV-2 Spike Protein in silico Interaction With ACE2 Receptors From Wild and Domestic Species. Front Genet. 2021;12:571707. doi: 10.3389/ fgene.2021.571707.

24. Michael HT, Waterhouse T, Estrada M, Seguin MA. Frequency of respiratory pathogens and SARS-CoV-2 in canine and feline samples submitted for respiratory testing in early 2020. J Small Anim Pract. 2021;10.1111/jsap.13300. doi:10.1111/jsap. 13300

25. Villanueva-Saz S, Giner J, Tobajas AP, Pérez MD, González-Ramírez AM, Macías-León J, González A, Verde M, Yzuel A, Hurtado-Guerrero R, Pardo J, Santiago L, PañoPardo JR, Ruíz H, Lacasta DM, Sánchez L, Marteles D, Gracia AP, Fernández A. Serological evidence of SARS-CoV-2 and co-infections in stray cats in Spain. Transbound Emerg Dis. 2021;9. doi: $10.1111 /$ tbed.14062

26. Klaus J, Palizzotto C, Zini E, et al. SARS-CoV-2 Infection and Antibody Response in a Symptomatic Cat from Italy with Intestinal B-Cell Lymphoma. Viruses. 2021;13(3):527. doi:10.3390/v13030527

27. $\mathrm{Na}$ W, Moon H, Song D. A comprehensive review of SARS-CoV-2 genetic mutations and lessons from animal coronavirus recombination in one health perspective. J Microbiol. 2021;59(3):332-340. doi:10.1007/s12275-0210660-4

28. Bonilauri P, Rugna G. Animal Coronaviruses and SARSCOV-2 in Animals, What Do We Actually Know?. Life (Basel). 2021;11(2):123. doi:10.3390/life11020123
29. Decaro N, Grassi A, Lorusso E, et al. Long-term persistence of neutralizing SARS-CoV-2 antibodies in pets. Transbound Emerg Dis. 2021 Sep 1. doi: 10.1111/tbed.14308.

30. Dileepan M, Di D, Huang Q, et al. Seroprevalence of SARS-CoV-2 (COVID-19) exposure in pet cats and dogs in Minnesota, USA. Virulence. 2021;12(1):1597-1609. doi:10.108 $0 / 21505594.2021 .1936433$

31. Yilmaz A, Kayar A, Turan N, et al. Presence of Antibodies to SARS-CoV-2 in Domestic Cats in Istanbul, Turkey, Before and After COVID-19 Pandemic. Frontiers in Veterinary Science 2021;8:1123. doi:10.3389/ fvets.2021.707368

32. Aydin H, Timurkan MÖ. SARS CoV-2 bulaşma ve replikasyon dinamiği. Eurasian Journal of Veterinary Sciences. 2020; 0(Covid-19 Special Issue): 17 - 22. doi: 10.15312/ EurasianJVetSci.2020.289.

33. Yeşilbağ K., Aytoğu G. Coronavirus host divergence and novel coronavirus (SARS-CoV-2) outbreak. CEOTI. 2020; 2(1): 6-14.

34. Yaglom HD, Hecht G, Goedderz A, et al. Genomic investigation of a household SARS-CoV-2 disease cluster in Arizona involving a cat, dog, and pet owner. One Health. 2021;13:100333. doi: 10.1016/j.onehlt.2021.100333. 